\title{
CHERNEL SZOBOR AVATÁSA AGÁRDON, A VELENCEI-TÓNÁL
}

\author{
Faragó Sándor \\ Soproni Egyetem, Vadgazdálkodási és Gerinces Állattani Intézet \\ University of Sopron, Institute of Wildlife Management and Vertebrate Zoology \\ H-9400 Sopron, Bajcsy-Zs u. 4., Hungary
}

\begin{abstract}
FARAGÓ S. (2019): INAUGURATION OF ISTVÁN CHERNEL'S SCULPTURE IN AGÁRD, AT LAKE VELENCE. Hungarian Small Game Bulletin 14: 201-207. http://dx.doi.org/10.17243/mavk.2019.201

On the 31st May 2015 a sculpture of the ornithologist ISTVÁN CHERNEL was unveiled in Agárd. ZSOLT SEMJÉN, Deputy Prime Minister inaugurated the work of the sculptor ANDRÁs KONTUR.
\end{abstract}

KULCSZAVAK: CHERNEL ISTVÁN, szobor, Agárd

KEY WORDS: IsTVÁN CHERNEL, sculpture, Agárd, Hungary

Szobrot állítottak Agárdon 2015. május 31-én CHERNEL ISTVÁN ornitológusnak. A szobrot, KONTUR ANDRÁs szobrászművész alkotását, SEMJÉN ZSOLT miniszterelnök-helyettes avatta fel. Avatóbeszédét az alábbiakban közöljük:
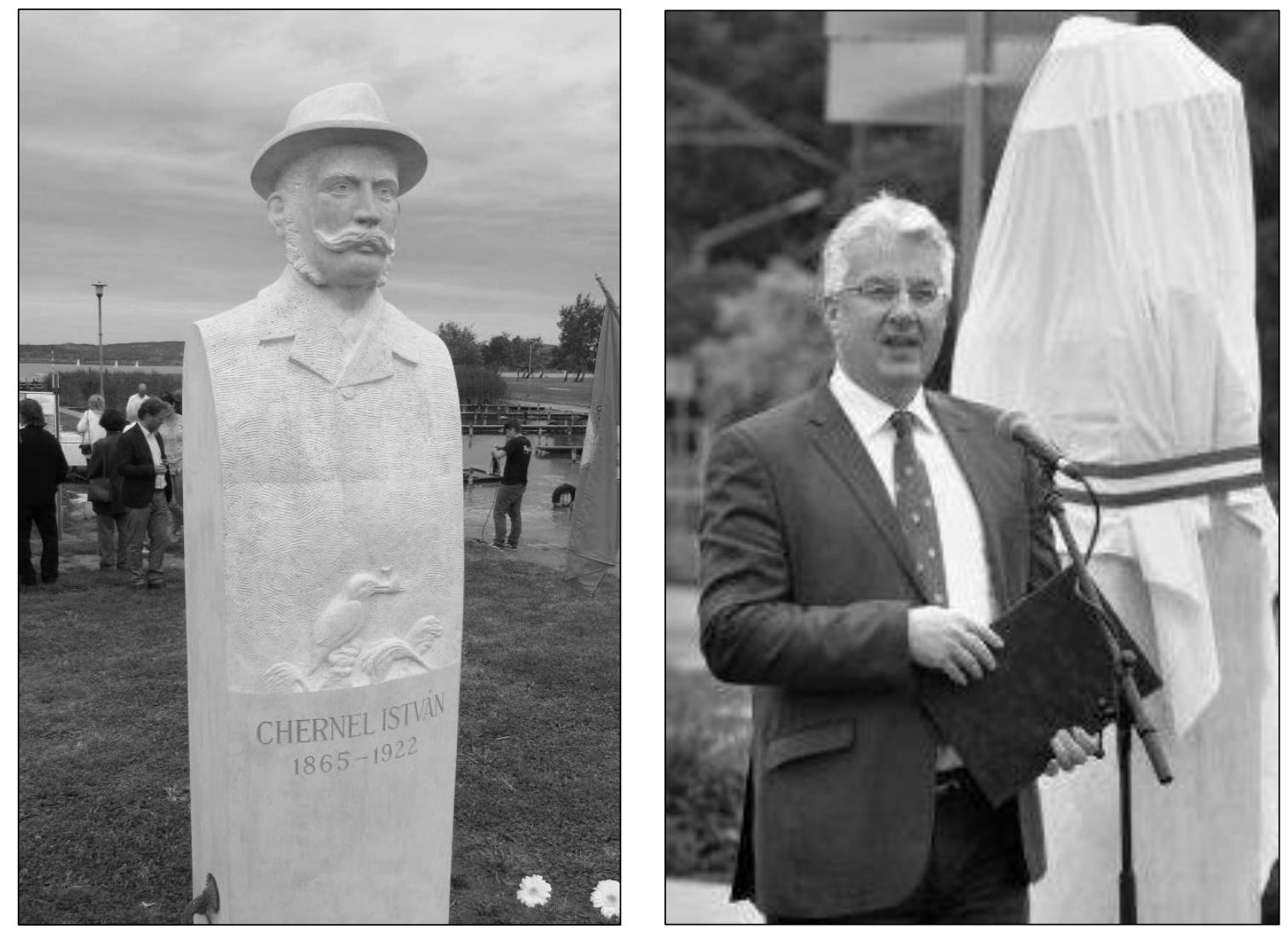

1. ábra: CHERNEL ISTVÁN agárdi szobra és az avatóbeszédet mondó SEMJÉn ZSOLT miniszterelnök-helyettes (Foto: MÁTHÉ Z. MTI)

Figure 1: ISTVÁN CHERNEL's sculpture in Agárd, and ZSOLT SEMJÉN, Deputy Prime Minister giving the inauguration speech 


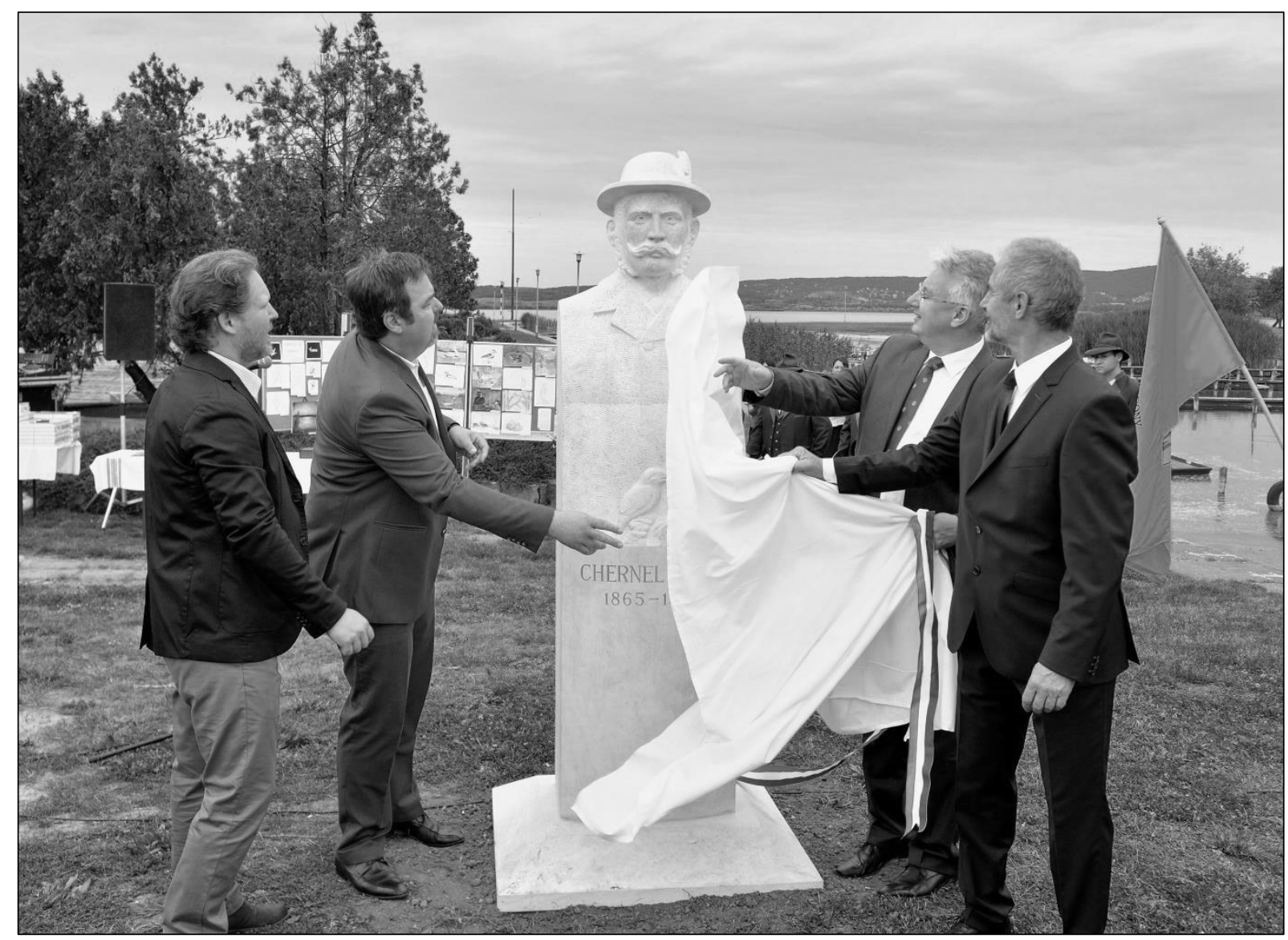

2. ábra: A CHERNEL szobor leleplezése (balról jobbra: KONTUR ANDRÁs szobrászmüvész, L. SIMON LÁSZLó államtitkár, SEMJÉN ZSOLT miniszterelnökhelyettes és TóTH ISTVÁN polgármester) (Foto: MÁTHÉ Z. MTI)

Figure 2: Unveiling of the CHERNEL sculpture (ANDRÁS KONTUR SCulptor, LÁSZLÓ L. SIMON undersecretery of state, ZSOLT SEMJÉN, Deputy Prime Minister and ISTVÁN TÓTH mayor)

\section{Tisztelt Ünneplök!}

Egy újabb álom valósult meg államtitkár úr és polgármester úr nagy ívü elképzeléséből, mármint, hogy a Velencei-tó parti sétányán létre jöhessen a tóért és környezetéért sokat tevő természettudósok és természetírók panteonja. A személyek kiválasztásában a kerek évfordulók a segítségükre siettek. Tavaly HERMANN OTTÓ halálának századik évfordulójára emlékeztünk, idén pedig CHERNEL ISTVÁN születésének százötvenedik évfordulóját ünnepeljük.

A két személy közel állt egymáshoz, mondhatnák: mester és tanítvány. 1916-ban, HERMANN OTTÓ halála után a Madártani Intézet vezetői székében CHERNEL IsTVÁN követte a nagy természettudóst. Tragikus módon csak rövid idő adatott neki, 1922-ben, még fiatalon elhunyt. Szülővárosában, Kőszegen helyezték örök nyugalomra, ahol számos emlék, így az általa létrehozott arborétum, a CHERNEL-kert emlékeztet munkásságára. De ne vágjunk a dolgok eleibe.

CHERNEL ISTVÁN olyan tehetség volt, akinek adottságait nemzedékek során át munkálta ki a természet. Már nagyapja természetszeretetében komoly rész jutott az ornitológiának. Édesapja ezt folytatta, esztendőről, esztendőre feljegyzéseket készített a madarak vonulásáról. ISTVÁN, mondhatjuk már a bölcsőtől hozta magával a természetszeretetet, és a tudományok iránti vonzódást. 
Mindazonáltal apja határozott kívánságára jogot végez, és közigazgatási gyakornokként helyezkedik el a megyénél, igaz egy jó évre rá beadja lemondását. Naplójának tanulsága szerint ekkor „börtönből szabadult sasnak” érzi magát.

Kutat, jegyzetel, múzeumban dolgozik, járja az országot, rajzol és fest, vadászik, de mindenekelött, megfigyel és gyüjt. Figyeli a madarak életét, de mindeközben feljegyzi vadászatra, halászatra vonatkozó szólásokat-mondásokat is.

„Mindig úgy vagyok az ornitológiával, mintha a gondviselés adta volna a lelkembe a hozzá való kedvet, és egy egész nemzet elött felelös lennék érette, mely megró, ha nem járok el benne lelkiismeretesen." - írja menyasszonyának. Lázasan dolgozott, és ez meghozta az eredményt. 34 éves korára összeállt az azóta is páratlan értékü könyve, a „Magyarország madarai".

Tanítványa róla szóló munkájában idézi azt a dedikációt, amit CHERNEL a szülei könyvébe írt: „Amit az örökké szép és mindig igaz Természet templomában, annyi sok helyen, annyi sok felejthetetlen órában egy fél életidőn át tapasztaltam, megfigyeltem és most áhitatos pillanatokban összefoglalva leirtam: íme, nyújtom át Nektek. Olvassátok és találjatok benne annyi élvezetet és tanulságot, mint amennyit a könyv alkotása szerzett."

Munkájához bejárta az országot „Kárpátoktól le az Al-Dunáig”, de mint írja „legtovábbra állapodtam meg a Fejér megyei kies Velencei tónál. A madáréletnek olyan hatalmas kibontakozására találtam ott, mely ritkítja párját, kivált a tavaszi és öszi vonulás szakában..."

Egy itthon és külföldön egyaránt hézagpótló, népszerü, igazi magyar alkotás született. Igen népszerü lett a mü, mert írója a szigorúan tudományos szemlélet mellett szívéneklelkének egész melegségével írta. Kérdezhetnék a kétkedők, mitől magyar egy tudományos mü? Nos, attól, hogy magyarul, magyar szellemben, magyar észjárással szól a magyarokhoz, és így adja ezt a világ tudtára.

Mert ez a könyv nem csak a madarakról és élet megnyilvánulásaikról szól. Az országot nyitott füllel járó szerző beleszőtte könyvébe a nép ajkáról hallott szólásmondásokat, elnevezéseket, közmondásokat, népdalokat. De ami a legkülönlegesebb, megjelenik az irodalom. Sorra olvashatjuk, hogyan is jelentek meg PETÖFI, ARANY, TOMPA MIHÁLY, VÖRÖSMARTY és társaik verseiben kedvenc madaraik.

\section{Hölgyeim és Uraim!}

Tegyünk most egy rövid kalandozást jeles költőink ornitológiájában, idézve szigorúan CHERNEL munkájából.

A gólya és a fecske a magyarság legválasztottabb tavasz hirdetője és nyár búcsúztatója.

„Haza tér a
Fecskemadár
Zöld ruhát ölt

Künn a határ” írja PÓSA LAJOS a tavaszról.

Vagy ugyanez TOMPÁNÁL:

„Megenyhült a lég, vidul a határ

S te újra itt vagy jó gólyamadár"

ARANY JÁNOS hívogató szóval várja őket:

„, Tavaszi fecskék, dal kedvesei

Jertek el Isten kömívesei"

„Jön az ösz megy a gólya már

Hideg neki ez a határ" 
Így búcsúztatja PETŐFI a madarat, máshol szól mindkettőről:

„Üres már a fecskefészek

Itt az eszterhéj alatt,

Üres már a gólyafészek

Tetején a kéménynek

Vándor népe ott halad"

A fecskéröl a népdalok is sürün szólnak:

„Nincs szebb madár a fecskénél

Barna piros menyecskénél"

Vagy szól a dal a kis ,postásról”:

„Menj szeretöm ablakába

Röpülj az ö szobájába

Te kis fecske azt izenem

Hogy ötet most is szeretem"

TOMPÁNÁL pedig ott van a haza iránt érzett fájdalmában:

„Neked két hazát adott a végzeted

Nekünk csak egy volt, az is elveszett"

TOMPA MiHÁly jó megfigyelö, s a madarak igen széles köréből merít verseiben, csak néhányat idézek:

„A bibic fenn kering

Vagy lenn begyeskedik"

„Ahol nemes túzok sétálgat a mezön

Amely nyúlárnyékot s ördögbordát terem"

„Szárcsák csapata óvakodva gyül

S a kotormányon hosszú sorba ül"

A kócsagról a nép körében az járta, ha egy puskás ember megsebesítette, és összevérezte magát, a büszke madár a véres tollait kitépkedte, ezt örökíti meg TóTH KÁLMÁN versében:

„Síró hattyú voltam szenvedéseim taván

Hanem majd ezután büszke kócsag leszek

Legdrágább tollait kitépi a madár

Ha gyilkos óntól összevéreztetett"

(Ha már éppen a kócsagnál tartunk, mindenképpen szólnunk kell arról, hogy 1901-től létezik hazánkban madárvédelmi törvény, ami akkor még a hasznos madarakra vonatkozott, de Európában először - pont a kócsag kapcsán - 1912-ben született jogszabály, védelem a kipusztulás elkerülése érdekében.)

De folytassuk még egy kicsit az irodalmi kalandozásunkat. Költőink sokat tudtak a madarakról, de odafigyeltek a néphagyományokra is. S miután az emberek eleve közelebb álltak a természethez, így bátran nyúltak a madarak tulajdonságai által felkínált hasonlatokhoz.

„Csak sast nemzenek a sasok” írja BERZSENYI a nagyságról, „, Vagyok pelikánja kietlen vadonnak" mondja ARANY. A szürke gém után nevezte a népnyelv gémlábúnak a németet:

„Isten hozzád gyáva német

Úgy nézlek mint tarka gémet" 
Halált, háborút hoz a kuvik BOZAY PÁL versében:

„S kiáltom kuvik tuhu

S mondják lesz dögvész háború”

A szarka, azon túl, hogy a tolvajra is használják, csörgésével érkező vendéget jósol. PETŐFI is kérdezi:
„Nos fiuk nem szólt a szarka
Házfödélteken?
Vagy ki álmodja meg, hogy ma
Vendégetek leszen?"

De megerősíti ezt a népdal is:

„Csörög a szarka a kerti fán

Vendég érkezik még ma tán"

A fülemile pedig a tiszta szerelem szimbóluma, megint csak PETŐFITŐL:

„Pedig én kakas nem vagyok

Hanem fülemile vagyok

Egy a fészkem egy a párom

Egyért élek a világon"

És persze a történelmi versekben is jelen vannak. CHERNEL könyvében a karvaly a turul. Ma leginkább a kerecsen sólyommal azonosítják. (De semmiképpen nem a millennium idején a szobrászatban divatossá vált keselyüábrázolással.) ARANY is külön szerepelteti őket a Keveházában:

„Azért vijjog a keselyü,

Azért szállong turul, s ölyü"

A mondásokban sokat szerepel a holló is. Holló volt, hattyú lett - mondják az őszülőre, beszélnek hollófürtökröl, Nagypénteken mossa a holló a fiát, utalnak korai költésére, és ARANY JÁNOS is megénekli a levélvivőt, talán legismertebb versében.

Az utóbbi időben öröm volt látni, hogy rangos, a természet világával foglalkozó lapjainkban, így a Nimród és az Állatvilág hasábjain nagyon szép és méltó írások jelentek meg CHERNEL ISTVÁNról.

Eddig a magyar madártan tudósáról beszéltem, de nekem, mint vadásznak okvetlenül említést kell tennem CHERNELről, a vadászról is, aki nemcsak hogy szenvedélyes vadász volt, de erről már kora ifjúkorában publikált, élvezetes vadásznaplót vezetett, munkálkodott a Nemzetközi Vadász Kongresszuson, és részt vett a vadászati törvényjavaslat előkészítésében. Vadászatában is - mint a madártanban -, egyesült benne a természet szeretete és a tudományosság.

Megjelenik ez könyvében is. Csak, hogy egyet felidézzek, igencsak szemléletesen ír a Velence tavi nagy tavaszi vadászatról, amin minden nevezetes vadász, ha tehette, részt vett. Ladikok tömkelege indult el a déli part felöl, átfogva az egész tavat. Mikor a vöcsök és réce hadakat a parthoz szorították, azok gyors repüléssel indultak visszafelé, akkor kezdődött a

vadászat. És löhettek bármennyit, ez másnapra már meg sem látszott, szinte ugyanannyi úszkált a tavon. Viszont a halgazdaság is jól járt a tavaszi vadászattal.

De tudunk még más érdekességet is róla. Norvégiai tanulmányútjáról hazatérve sítalpakkal felszerelkezve érkezett meg. Öt tartjuk a magyarországi síelés meghonosítójának. 1897-ben megjelentette „A lábszánkózás kézikönyve” munkát - ami ma már keresett könyvritkaság -, a síelésről szóló első kézikönyv. 


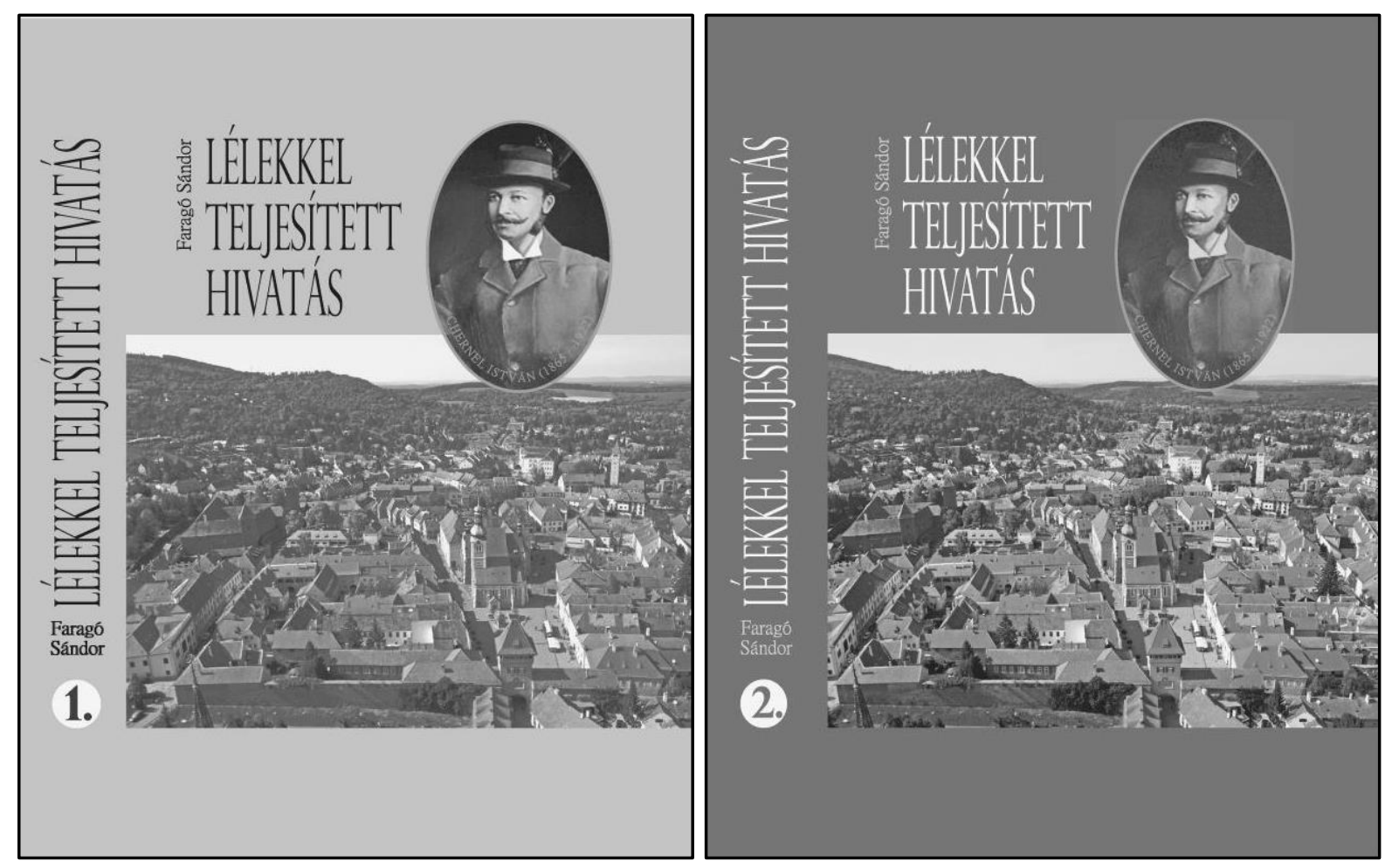

3. ábra: A CHERNEL szobor avatása alkalmával bemutatott könyv: FARAGó S. (2015): Lélekkel teljesített hivatás. Nyugat-magyarországi Egyetem Kiadó, Sopron Figure 3: First book presented during the CHERNEL sculpture inauguration

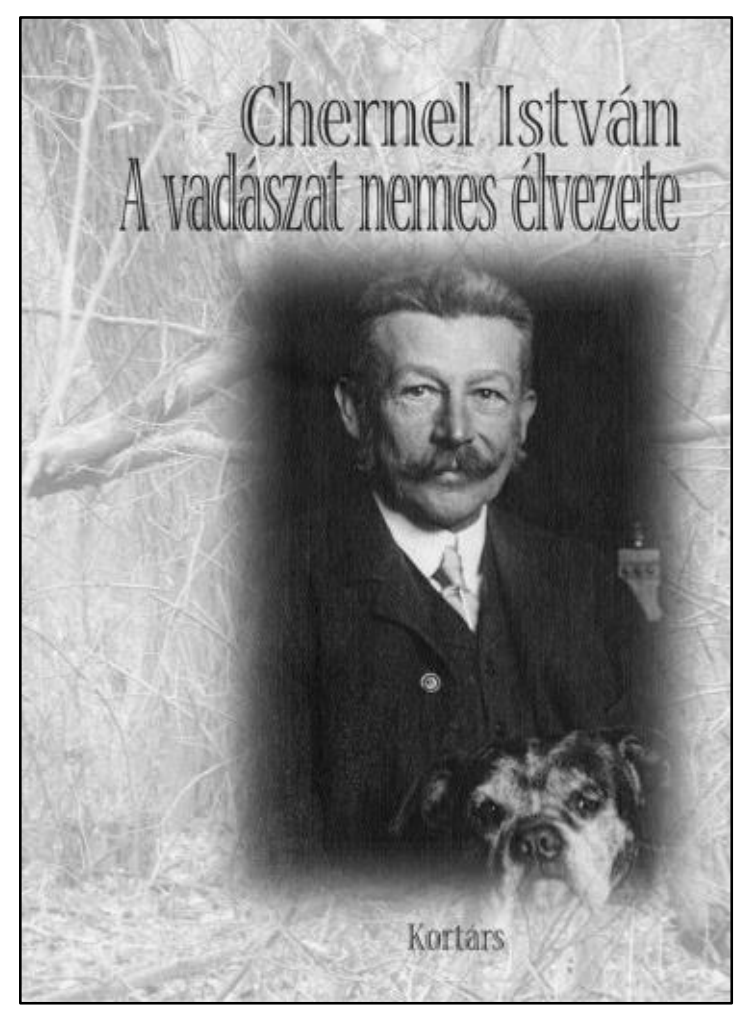

4. ábra: A CHERNEL szobor avatása alkalmával bemutatott könyv: CHERNEL I. (2015): $A$ vadászat nemes élvezete (Szerk. MAJTHÉNYI L.). Kortárs Könyvkiadó, Budapest

Figure 3: Second book presented during the CHERNEL sculpture inauguration 
Köszönet illeti mindazokat, akik munkálkodtak azon, hogy CHERNEL IsTVÁN szobrot kapjon itt a tóparti panteonban, és köszönet mindazoknak, akik azért tesznek, hogy kiváló tudósunk mind szélesebb körben ismertté váljon!

L. SIMON LÁSZLÓ a Miniszterelnökség parlamenti államtitkára bemutatott két könyvet is, FARAGÓ SÁNDOR: Lélekkel teljesitett hivatás kétkötetes munkáját, CHERNEL monográfiáját, illetve MAJTHÉNYI LÁSZLÓ válogatásában és szerkesztésében $A$ vadászat nemes élvezete, címü könyvet, CHERNEL ISTVÁN vadászati írásaiból és vadásznaplóiból

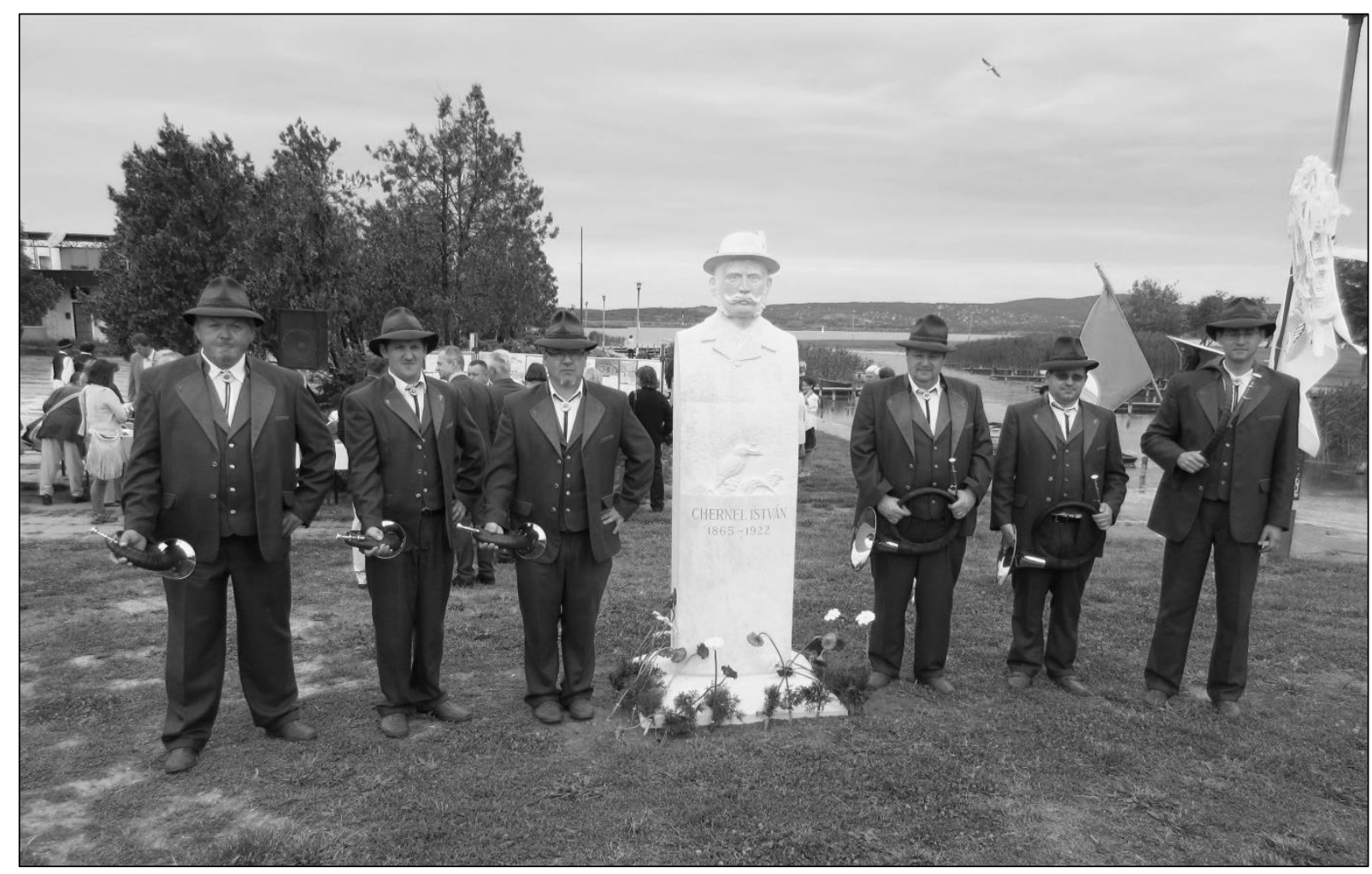

5. ábra: A CHERNEL szobor avatása

Figure 5: The CHERNEL sculpture inauguration 
